\title{
CHALLENGES OF AL ISLAM AND KEMUHAMMADIYAHAN (AIK) LEARNING WITH BAITUL ARQAM MODEL
}

\author{
Tri Santoso ${ }^{1}$, Giyoto$^{2}$, Baidi ${ }^{3}$, Hari Kusmanto ${ }^{4}$ \\ 1,2,3Islamic Educational Management Department, Institut Agama Islam Negeri Surakarta, \\ Sukoharjo, Central Java, Indonesia \\ ${ }^{4}$ Indonesian Language Education Department, Universitas Muhammadiyah Surakarta, \\ Sukoharjo, Central Java, Indonesia \\ Email: masbungts@gmail.com¹, p.giyoto@gmail.com², baidi.iain@gmail.com³ \\ harikusmanto.ums@gmail.com ${ }^{4}$
}

DOI: http://doi.org/10.33650/al-tanzim.v5i1.1644

Received: December 2020 Accepted: February 2021 Published: March 2021

\begin{abstract}
:
This study aimed to describe the implementation of AIK learning program with the Baitul Arqam model at the Muhammadiyah University of Surakarta in the 2019/2020 year. This study employed a qualitative approach to research. In collecting data, this study used observation, in-depth interviews, and documentation techniques, while the data validation was a triangulation of data sources and theories. This study's data analysis applied a CIPP Stufflebeam analysis. The results showed that (1) evaluating the AIK learning program with the Baitul Arqam model can be stated quite well in planning, organization, and implementation. The evaluation results on the supervision aspect of AIK learning program within the Baitul Arqam model can be unfavorable. (2) The challenges faced by the AIK learning program with the Baitul Arqam model included: (a) the need for strategic planning, (b) qualified educators based on the standards, (c) a campus environment, and (d) an integrated supervision model.
\end{abstract}

Keywords: Baitul Arqam, Management, Evaluation, CIPP

\begin{abstract}
Abstrak:
Penelitian ini bertujuan mendeskripsikan proses pelaksanaan program pembelajaran AIK model Baitul Arqam di Universitas Muhammadiyah Surakarta Tahun 2019/2020. Pendekatan yang digunakan dalam penelitian ini adalah kualitatif. Pengumpulan data penelitian ini menggunakan teknik observasi, wawancara mendalam, dan dokumentasi. Validasi data dalam penelitian ini menggunakan trianggulasi sumber data dan teori. Analisis data penelitian ini menerapkan analisis CIPP Stufflebeam. Hasil penelitian menunjukkan (1) evaluasi program pembelajaran AIK model Baitul Arqam dapat dinyatakan cukup baik pada aspek perencanaan, pengorganisasi, dan pelaksanaan. Adapun hasil evaluasi pada aspek pengawasan program pembelajaran AIK model Baitul Arqam dapat dinyatakan kurang baik. (2) Tantangan-tangan yang dihadapi program pembelajaran AIK model Baitul Arqam meliputi: (a) perlu perencanaan strategis, (b) tenaga pendidik yang memiliki kualifikasi sesuai dengan standar, (c) lingkungan kampus yang mendukung pembiasaan beribadah, dan (d) model pengawasan yang terintegrasi.
\end{abstract}

Kata Kunci: Baitul Arqam, Managemen, Evaluasi, CIPP 


\section{INTRODUCTION}

The importance of assessing education delivery programs in tertiary institutions is that, through periodic evaluations, weaknesses and advantages of the programs implemented can be identified. Further improvements and development of better plans can be carried out (McDavid et al., 2018; Widoyoko, 2017)). Therefore, the urgency of evaluating education delivery programs in tertiary institutions is critical to maintain and improve the program quality (Norton, 2014).

Muhammadiyah University of Surakarta (UMS) is one of the higher education institutions given the authority to organize educational programs at the tertiary level. Managing higher education aims to equip students with religious-spiritual strength, self-control, personality, intelligence, noble morals, and skills needed by themselves, society, nation, and state. One of the ways to achieve higher education goals is through the learning process or lectures.

One of the lecture forms conducted at UMS is to achieve the goals of higher education and equip students with religious-spiritual strength, selfcontrol, personality, intelligence, noble morals, and skills needed by themselves, society, the nation, and the state through the Al Islam and Kemuhammadiyahan (AIK) learning program with Baitul Arqam model. The AIK learning program with the Baitul Arqam model is AIK learning carried out with a cottage system for four days and three nights or the equivalent of sixteen face-to-face meetings in effective learning in the classroom.

The AIK learning program with such a cottage system is available merely at UMS. Several Muhammadiyah universities, such as the Muhammadiyah University of South Tapanuli, Muhammadiyah University of Yogyakarta, and Ahmad Dahlan University, attempt to imitate and collaborate on this program. Still, none of them succeed as UMS does. While other tertiary institutions that follow this program have limited the research participants to students of the Islamic Faculty (FAI) only, UMS, in contrast, has implemented the AIK learning with Baitul Arqam model to students of all faculties in the first and second semesters.

Besides, the other universities do not satisfactorily achieve learning outcomes as UMS does in the AIK learning with Baitul Arqam. This is because students feel burdened to achieve the learning objectives in one semester, condensed into four days and three nights. The lack of lecturers' creativity and ability to learn is also one of the reasons why the AIK teaching programs are less successful in other universities. The Baitul Arqam activity is a part of learning. Learning is defined as a process in which a person's environment is deliberately managed to allow students to participate in certain behaviors under particular conditions or produce responses to certain situations; learning is a specific sub of education (Corey, 2013).

The problem of this study is that the implementation was carried out for four days and three nights with 16 meetings and is included in a value system contrary to higher education's national standards. In addition to program implementation, there are also teaching staff who do not match the qualifications specified in Law Number 14 of 2015 concerning Teachers and 
Lecturers, which states that the lecturers who teach undergraduate programs should at least complete a master's degree (S2). Among the teaching staff involved in the AIK learning with Baitul Arqam model, only $40 \%$ of them have been awarded a master's degree (S2).

Moreover, viewed from the perspective of course output, the AIK learning program with the Baitul Arqam model is considered ineffective. It is expected that students need to be accustomed to carrying out compulsory worship and sunnah in the congregation. It is difficult to achieve if it is only done within four days and three nights. Another problem is the absence of an integrated supervisory system between the LPPIK as the learning organization and the university, dean, and study program. Furthermore, the follow-up of Baitul Arqam is a mentoring program that has not been in line with the goals of Baitul Arqam. Mentoring only focuses on eradicating illiteracy in Arabic or in reading the Al-Qur'an. In other words, there is a missing link between the program objectives and the follow-up of the AIK learning program.

Even though this program has been conducted since 2005, there has not been a comprehensive management evaluation of the AIK learning program with the Baitul Arqam model,). Ideally, the evaluation of each program is carried out every semester to determine the effectiveness of activities and the achievement of goals. This enables to immediately correct any errors or deviations from the objectives that have been set (Lyngdoh \& Dhaliwal, 2018; Sugiyono, 2018). Properly managed and evaluated, the strategy can improve the program quality and increase the achievement index for the stated objectives in the form of Graduate Competency Standards (SKL).

To fill in the blanks that have not been done, there has not been a comprehensive evaluation from 2005 to 2020 . This study examines the ways to evaluate the AIK learning program with the Baitul Arqam model at UMS for the 2019/2020 academic year. The purpose of this study is to assess the AIK learning program with the Baitul Arqam model at UMS for the 2019/2020 academic year.

Learning management can be interpreted broadly to include all activities on how to teach students from planning to program evaluation. Connolly et al. (2019) define learning management as all efforts to regulate the teaching and learning process to achieve an effective and efficient teaching and learning process. Learning program management is often referred to as curriculum and learning management.

Learning management is the arrangement of all learning activities, whether categorized based on the core or supporting curriculum based on the curriculum that has been previously determined by the Ministry of Religion or the Ministry of Education and Culture and further developed by universities along with the existence of higher education autonomy (Irianto, 2012). Therefore, universities can make development and innovation efforts in curriculum management. Jiao \& Deng (2019) define learning leadership as a systematic effort made by educational institutions (campuses/schools/madrasahs) in planning, organizing, mobilizing, and supervising curriculum implementation activities and learning as a strategy for 
educational instantons to adapt the process of cultural inheritance (culture) both within and as well as external educational institutions to achieve predetermined goals.

Based on the definition of 'experts' reports and statements, learning management can be distinguished in a broad sense and a narrow one. In the general sense, learning management involves managing how to teach learners with activities starting from planning, organizing, directing, or controlling and evaluating. Learning management in a narrow sense is defined as activities that need to be managed by educators during the interaction process with students in the implementation of learning. Thus, the things that need to be considered in learning management are as follows: Lecturer-student activity schedule; learning strategies; practice material management, management tools; team learning; remedial and enrichment programs; and improving education quality.

Siswanto (2016) formulate management objectives as something to be realized, which describes a specific scope and suggests a direction to a manager's efforts. Based on this formulation, four essential or principal elements can be taken as goals, namely: 1) something to be realized (intent); 2) scope; 3) definiteness; 4) direction of learning management objectives to determine the learning objectives, the size of learning, the time required and directed according to the learning mechanism that has been set.

Hamalik as quoted by Syam (2017) state that the scope or component of learning management includes students (students), educators (teachers/lecturers), objectives, materials, methods, tools/tools/media, evaluation, and learning environment.

The program results from a decision from an institution; this is more specific than the policy, and the goals are more concrete (Magdalena et al., 2020; Mulyatiningsih \& Nuryanto, 2014). The program is run with management. Management is achieving goals set through or together with others' efforts (Terry, 2019). In the process of running the program, it must be appropriately managed by the management function (planning, organizing, implementing, and monitoring) and evaluated to determine whether the program is running effectively based on the objectives or not.

Stoner \& Wankel (1988) define management as planning, organizing, leading, and controlling organization members' effort and using all other organizational resources to achieve stated organizational goals.

CIPP evaluation is an evaluation concept of a program by focusing on four aspects. These four aspects include Context, Input, Process, and Product (Stufflebeam \& Coryn, 2014). The explanation of each of these aspects is presented below.

\section{RESEARCH METHODS}

This study employed a qualitative approach (Graue, 2015; Toro et al., 2013; Zurqoni et al., 2019). This approach aims to obtain a generalized description of the implementation of AIK learning program with the Baitul Arqam model.

The participants of the study were students, lecturers, and managers involved in implementing the AIK learning program with the Baitul Arqam 
model. The informant in this study was also the rector as the leader of the college. The data collection was carried out using observation, in-depth interviews, and documentation methods (Creswell, 2016; Flick et al., 2017). This study observed the implementation of AIK learning program with the Baitul Arqam model at the Muhammadiyah University of Surakarta. The researchers played as observers and recorded every moment in the learning process (nonparticipant observatory) of the AIK learning program with the Baitul Arqam model. The researchers paid attention to the activities of implementing the AIK learning program with the Baitul Arqam model, starting from the placement and scheduling stage of the program, the learning process, to the completion of learning, which was four days and three nights. It was through this data collection technique that an initial description of the implementation process of Baitul Arqam was obtained. To validate data, triangulation of data sources and theories were applied. The analysis technique used in this study was the interactive model by Miles \& Huberman.

\section{RESULTS AND DISCUSSION}

Results and discussion of this study focus on evaluating the CIPP program on the management function and challenges of the AIK learning program with the Baitul Arqam model.

\section{Planning the AIK Learning Program with Baitul Arqam Model}

Based on the study results, the researchers found that the AIK learning program with the Baitul Arqam model has been planned. It is manifested in a document in the form of a guidebook for implementing the AIK learning with the Baitul Arqam model. The components contained in the guidebook include (1) background, (2) vision and mission, (3) goals and targets, (4) organizers or managers, (5) team of facilitators or lecturers, (6) curriculum, (7) methods and strategies, (8) evaluation system, (9) duties and code of ethics for facilitators, priests or co-priests training, (10) schedule of Baitul Arqam I and II, (11) followup, (12) life motto and (13) UMS march, 'Aisyiyah march and Muhammadiyah march and calendar. The planning is intended to achieve the AIK learning objectives in the Baitul Arqam model.

Context evaluation relates to whether or not planning is based on student needs. Context evaluation aims to assess whether the objectives that have been set meet the needs of those who are the organization's target (Mahmudi, 2011). The study-targetted parties are UMS students who participate in the AIK learning program with the Baitul Arqam model. Hence, the function of context evaluation on planning management is related to whether the planning has involved various parties and to what extent the planning objectives will be achieved (Wulogening \& Timan, 2020). The results of the context evaluation on planning management are quite good. It means that planning has involved various parties such as the LPPIK team, university leaders, teachers, and stakeholders (students). However, it is felt that the objectives to be achieved will be challenging to accomplish because the planning of learning outcomes focuses on the habituation aspect of worship. The habituation cannot be attained in such a short time, which is four days and 
three nights. This is in line with Mutakin et al., (2014) that habituation can get good results if it is done with repetitive exercises and habituation. Therefore, it will be challenging to achieve the planned learning outcomes.

Input evaluation is an advanced evaluation that supports the achievement of the AIK learning program with the Bath actual Arqam model. Input evaluation is related to aspects of facilities and infrastructure availability (Junanto \& Kusna, 2018). Furthermore, input evaluation is also related to students, lecturers, and infrastructure (Muyasaroh \& Sutrisno, 2014). The review of the input of the Baitul Arqam model of the AIK learning program planning committee is quite good. It means that several things do not meet the planning standard, for example, in the aspect of facilitators or lecturers who have not qualified according to predetermined criteria. Even though learning is carried out well, it still needs to be supported by teachers who have high competence and the ability to determine the quality of education (Rochmawati, Timan, \& Kusumaningrum, 2019).

Process evaluation is related to the implementation process of AIK learning program with the Baitul Arqam model. Furthermore, process evaluation in the CIPP model is directed to the extent to which the planned activities are carried out (Refita, Siregar, \& Imam, 2017). Process evaluation in planning management is dealt with whether the lesson plan is based on planning standards. The results of process evaluation in planning management can be declared right. This is based on the planning of the AIK learning process with the Baitul Argam model arranged in such a way as to the time, place, and facilitators, and even the learning evaluation system used.

Product evaluation is related to the results of the plans that have been prepared. Miswanto (2016) states that product evaluation is directed to things that show changes and occur in raw inputs. Product evaluation in the planning management function is intended to determine whether the plans prepared have been achieved and whether the projects that have been trained can accommodate students' needs. The results of the evaluation of planning management products indicate that the planning objectives have not been achieved. This can be seen from the planned learning outcomes, and the designed evaluation system is not suitable. The learning outcomes intended for the AIK learning program with the Baitul Arqam model are; (1) students have an integrated understanding of Islamic teachings based on the Al-Qur'an and AsSunah (habituation of worship). (2) Students can practice worship properly according to the Al-Qur'an and As-Sunah in their daily life. (3) Students have akhlaqul karimah and dress Muslim according to Islamic law. However, the evaluation system carried out is still limited to when students are at the college. It means that the evaluation outside the boarding school has not been carried out, so that the learning outcomes have not been fully achieved. 


\section{Organizing the AIK Learning Program with Baitul Arqam Model}

Organizing the AIK learning program with the Baitul Arqam model is carried out by making fields with their respective responsibilities under the executive chairman of Baitul Arqam. The areas are (1) human resources (facilitators, priests, and co-priests training), (2) dormitories, (3) facilities and infrastructure, (4) health, (5) transportation, (6) security sector, (7) public relations sector, (8) IT sector, and (9) general assistant. This shows that the AIK learning program manager with the Baitul Arqam model has implemented the organizational management function. Organizing during the Covid-19 pandemic is different from face-to-face meetings. Namely, students are more active in coordinating with facilitators to make the AIK learning process with the Baitul Argam model online successful.

Context evaluation on the organizational aspects of AIK learning program with the Baitul Arqam model relates to planning, management, vision and mission, and division of tasks. The results of the context evaluation on the elements of organizational management can be stated as good. This is based on the existence of transparent stewardship or management and division of labor. This success is inseparable from the role of leaders who prioritize transparency and high accountability to become a generator driving all personnel in the organization to work optimally according to the management of good educational principles (Abrori, 2018).

Input evaluation on the management aspects of organizing the AIK learning program in the Baitul Arqam model is related to the availability of facilitators or lecturers who are by predetermined standards or not. As for the middle of facilitators or lecturers who meet the qualifications, bachelor lecturers must hold a master's degree. The results of the input evaluation on the aspect of organizational management are quite good. This is based on the number of facilitators or lecturers, where from twenty-six facilitators, only five of them have master's qualifications. This needs immediate attention, considering that UMS as a reputable university must also be supported by lecturers who have adequate capabilities. If a university has qualified and competent lecturers, higher education development and performance will automatically increase (Muhtarom, 2015). In connection with lecturers' qualification problems, the AIK learning program manager with Baitul Arqam needs to respond by asking lecturers who do not have standard qualifications to take a master program.

Process evaluation on the aspect of organizational management can be stated quite well. This means that the learning organization still has some shortcomings, namely the instructor of each material has no clear name information, and only the facilitator or lecturer team mentioned it. This will impact students who, for example, have problems with poor grades, having to find the lecturer concerned.

Product evaluation in the aspect of organizational management can be stated as good. This is based on the policy of the Baitul Arqam model of the AIK learning manager, which has previously selected Baitul Arqam participants. Also, the manager has used the budget as much as possible to meet the needs of students while participating in the AIK learning program with the Baitul Arqam model for four days and three nights. 


\section{Implementing the AIK Learning Program with Baitul Arqam Model}

Implementing the AIK learning program with the Baitul Arqam model is first divided into student schedules and student quotas. This was done to run according to plan considering many UMS students so that the program was divided. At the time of face to face, the class can be filled with up to 60 students. However, at the time of the online model, the quota was limited to 40 students. This was done to facilitate supervision.

The sharing schedules are carried out directly by the manager by looking for new student data at UMS, then sorting them, students who are obliged to participate in Baitul Arqam and students who are not obliged. Compulsory students are undergraduate students, while postgraduate and vocational school students are not obliged to attend Baitul Arqam. Meanwhile, students register to take part in Baitul Arqam online through the manager's link.

The AIK implementation learns with the Baitul Arqam model both faceto-face and online for four days and three nights. On the first day, there is an opening and a public lecture delivered by the leadership of the LPPIK UMS. At this opening, students will be briefed during the AIK learning program with the Baitul Arqam model, which is carried out for four days and three nights. Also, there will also be briefings regarding the rules and witnesses of violations while participating in the AIK learning program with the Baitul Arqam model.

The AIK learning with the Baitul Arqam model is carried out for four days and three nights at the Hajjah Nuriyah Shobron Islamic Boarding School. This is different if done online, which is done from individual homes or student residences. The AIK learning materials studied for four days and three nights, both face-to-face and online, include ethics and fashion of dress according to Islamic law, Aqidah, Thoharoh, compulsory prayers, and sunnah prayers, morals, and congregational prayers in the AIK learning program with Baitul Arqam I. In the Baitul Arqam II model of the AIK learning program, students will learn about fasting, jamak and qasar prayers, zakat, haj and umrah, marriage in Islam, sacrifice, various kinds of prostrations and eclipse prayers, inheritance, business in Islam, caring for corpses, and materials Guidelines for Islamic Life for Muhammadiyah Citizens (PHIWM).

Context evaluation in the implementation management aspect is related to the AIK learning process with the Baitul Arqam model. The context evaluation results on the management aspects of implementing the AIK learning program with Baitul Arqam can be declared right. This can be seen with the AIK learning program policies and decisions with the Baitul Arqam model quickly. At the time of the Covid-19 pandemic, the manager immediately compiled an online Baitul Arqam model AIK learning design carried out for four days and three nights through online media in the form of a WA group Schoology, Google Classroom, and Zoom Meeting. The learning model includes presentations, giving assignments, or studying a problem based on the specified material.

The evaluation of input on the management aspects of implementing the AIK learning with the Baitul Arqam model can be stated as not useful. It means that the AIK learning program manager is good at making policies related to 
online AIK learning the Baitul Arqam model. However, the manager lacks in contributing to the financing of online AIK learning with the Baitul Arqam model. This can also be seen from the university policy that issued a two hundred thousand rupiahs UKT discount to buy a quota for one semester covering all the current semester courses. Meanwhile, the Ministry of Education and Culture in providing subsidized allocations is quite a lot. However, the learning media used in the AIK learning program am with the Baitul Arqam model is not by the learning media platform within the quota coverage given by the Ministry of Education and Culture, so that large quota cannot be used to access online learning media used by the AIK learning program with Baitul Arqam model.

Process evaluation on the management aspects of the implementation of the AIK leathering of the Baitul Arqam model is related to the extent to which the performance is by the plan that has been compiled. The evaluation of the implementation process of the Baitul Arqam AIK learning model can be declared right. It can be seen from the facilitators or lecturers who have carried out the lesson as much as possible by the previously prepared plans. The facilitator and students have also done their best to achieve the learning outcomes planned during the study.

Product evaluation on process management is related to the impact of participating in the AIK learning to reprogram the actual Arqam model and after participating in the AIK program the Baitul Argam model. The results of product evaluation on the management aspects of the learning process are quite good. It means that several things have worked but also several things that need attention. The impact that occurs when participating in the AIK learns the program with the Baitul Arqam model can be declared right. The learning outcomes that have been planned can be achieved well; students are accustomed to carrying out congregational prayers and night prayers.

\section{Controlling (Supervising) of the AIK Learning Program with Baitul Arqam Model}

Supervision is carried out by the AIK learning program with Baitul Arqam by monitoring the AIK learning process in the Baitul Arqam model, either directly or indirectly, through a facilitator. This supervision is also carried out on students, whether the students who take part are the students concerned or other students as jockeys-remembering that a student plays a jockey role. However, this is immediately apparent. This is one of the importance of supervision. Also, management is intended to determine whether learning outcomes are practical and efficient (Syamsuddin, 2017). The interview results show that the AIK learning program supervision with Baitul Arqam is only limited to the learning process, both face-to-face learning and online learning. Post-learning management is not carried out.

The evaluation results on the management aspects of the AIK learning program supervision with Baitul Arqam are related to how the supervision function in planning is structured. Based on the evaluation of the context of the AIK learning program, the Baitul Arqam model can be declared quite good. The supervisory function in planning is only during the learning process. However, 
achieving planned learning outcomes requires a supervisory role after students take the AIK learning program with Baitul Arqam. In contrast, the supervisory function in program planning is only carried out when students take the Baitul Arqam model learning. Therefore, it is necessary to have a supervisory role following the Baitul Arqam model of learning to achieve learning outcomes in planning.

Input evaluation on the management aspects of the AIK learning program supervision with Baitul Argam regarding leadership adjusted to the budget. Based on the results of the evaluation of the input on the aspect of supervision management, it can be stated well. It means that the manager has carried out a supervisory function adjusted to the budget for the AIK learning program with the Baitul Arqam model for four days and three nights. Students are given the right to eat ten meals for four days and three nights. Apart from that, the facilities and infrastructure are also quite adequate. Facilities and infrastructure are essential things to provide because educational programs' success is greatly influenced by facilities and infrastructure conditions (Khikmah, 2020).

Process evaluation on supervisory management is related to supervision during the AIK learning implementation with the Baitul Arqam model. Based on the process evaluation results on the AIK learning program management aspects, the Baitul Arqam model can be declared right. It means that the facilitator or lecturer has provided adequate supervision to students. This can be seen in various activities carried out while students are in the cotoversights in following lessons, leadership in carrying out congregational prayers, night prayers, etc.

Product evaluation on the supervisory management aspect of the AIK learning program with Baitul Argam is related to the supervision of learning outcomes, both leadership when students are in the cottage and control outside the house or on campus. The results of product evaluation on the management aspects of the AIK learning supervision with the Baitul Arqam model can be stated quite well. This can be seen from the supervisory function, which was only carried out when students were in the cottage. The supervision after participating in the AIK learning with the Baitul Arqam model is not carried out even though continuous leadership and coaching in each program are important (Change, 2019).

\section{The Challenges of AIK Learning Program with Baitul Arqam Model}

Based on the CIPP evaluation results of the AIK learning program with the Baitul Arqam model, several challenges must be faced. The challenges of learning AIK in the Baitul Arqam model include facilitators or educators, campus environment, and integrated supervision models. The detail can be seen in the following explanation.

\section{Teachers}

The next challenge is human resources or teaching staff who have qualifications by the standards that have been determined, namely lecturers for undergraduate students with minimum master qualifications (S2) and 
undergraduate students with minimum qualifications (S3). The teaching staff's condition in the AIK learning program with Baitul Arqam was twenty-six lecturers who have capabilities according to the standards, and only five out of twenty-six were mentioned. This is a challenge for managers to encourage and facilitate lecturers who have not met the qualifications to carry out further studies immediately.

\section{Campus environment}

The next challenge is a campus environment that supports students in implementing Islamic values, especially those learned when students take the Baitul Arqam model of AIK learning program and Islamic values known to students before participating in Baitul Arqam. Creating a supportive environment is an important thing to do; if the opposite happens, the AIK learning carried out with the Baitul Arqam model cannot be followed up by students because the campus environment is not supportive. This is certainly different if the learning outcomes at Baitul Arqam can be achieved because it is such a supportive environment.

In connection with the campus environment, it is essential to achieve the AIK learning outcomes in the Baitul Arqam model. There need to be policies from higher education leaders who collaborate with various parties such as the LPPIK to create a campus environment based on Islamic values. This began to be initiated by UMS, namely when lectures were taking place and showing prayer times, such as the noon prayer at 12:00 WIB. All campus activities have to be stopped and carried out congregational prayers at the mosque. However, it is difficult to apply in its implementation because many lecturers ignore it. Likewise, students who should pray in the congregation are also neglected to go to the canteen, in the park, etc.

\section{Integrated Supervision Models}

The next challenge of learning AIK in the Baitul Arqam model is related to the supervision model. The supervision carried out so far is still limited to when students are following Baitul Arqam. It means that after Baitul Arqam, there is no more supervision. This causes learning outcomes not to be achieved or to decrease. Thus, it is necessary to have an integrated supervisory model with each student's faculties and study programs. This supervision can later be used as a follow-up after participating in the AIK learning program am with the Baitul Arqam model.

\section{CONCLUSION}

Based on the results and discussion described, it can be concluded that the evaluation of the AIK learning program model with the Baitul Arqam model can be stated quite well in the aspects of planning, organization, and implementation. The evaluation results on the AIK learning program supervision aspect with the Baitul Arqam model can be stated to be unfavorable. Program control is carried out only when students attend Baitul Arqam. Program control that was carried out after participating in the AIK learning model of the Baitul Arqam was not carried out. 
The challenges faced by the AIK learning program with the Baitul Arqam model included: (a) the need for strategic planning, (b) qualified educators based on the standards, (c) a campus environment, and (d) an integrated supervision model. If these challenges can be overcome, the learning outcomes of AIK will be realized in campus life.

\section{REFERENCES}

Abrori, H. (2018). Inspiring Leadership dan Transformasi Kelembagaan Menuju Perguruan Tinggi Islam yang Unggul. Al-Tanzim: Jurnal Manajemen Pendidikan Islam, 2(1), 1-22.

Connolly, M., James, C., \& Fertig, M. (2019). The Difference between Educational Management and Educational Leadership and The Importance of academic Responsibility. Educational Management Administration E Leadership, 47(4), 504-519.

Corey, G. (2013). Teori dan Praktek: Konseling \& Psikoterapi. Bandung: Refika Aditama.

Creswell, J. W. (2016). Research design: pendekatan metode kualitatif, kuantitatif, dan campuran. Yogyakarta: Pustaka Pelajar.

Flick, U., Steinke, I., \& Kardoff, E. (2017). Buku Induk Penelitian Kualitatif, Paradigma, Teori, Metode, Prosedur, dan Praktik. Cantrik Pustaka: Yogyakarta.

Graue, C. (2015). Qualitative Data Analysis. International Journal of Sales, Retailing \& Marketing, 4(9), 5-14.

Irianto, S. (2012). Otonomi Perguruan Tinggi: Suatu Keniscayaan. Jakarta: Yayasan Pustaka Obor Indonesia.

Jiao, L., \& Deng, S. (2019). Research on Prominent Problem and Solution of Educational Management in Colleges and Universities Against the New Era Background. 2nd International Conference on Contemporary Education, Social Sciences and Ecological Studies (CESSES 2019), 946-948.

Junanto, S., \& Kusna, N. A. A. (2018). Evaluasi Program Pembelajaran di PAUD Inklusi dengan Model Context, Input, Process, adn Product (CIPP). Inklusi Journal Disability Studies, 5(2), 179-194. https://doi.org/10.14421/ijds.050202

Khikmah, N. (2020). Manajemen Sarana dan Prasarana untuk Mengembangkan Mutu Pendidikan. JAMP: Jurnal Adminitrasi dan Manajemen Pendidikan, 3(2), 14-21.

Kurniawati, P. I., \& Sayuti, S. A. (2013). Manajemen Sarana dan Prasarana di SMK N 1 Kasihan Bantul. Jurnal Akuntabilitas Manajemen Pendidikan, 1(1), 98-108.

Lyngdoh, L., \& Dhaliwal, R. K. (2018). Program Evaluation and Review Technique (PERT) in Agriculture. Indian Journal of Extension Education, 54(4), 54-58. 
Magdalena, I., Rosnaningsih, A., Akbar, M., \& Situmorang, R. (2020). Evaluasi Program Gerakan Literasi Sekolah di Sekolah Dasar Wilayah Kota dan Kabupaten Tangerang. Pendas: Jurnal Ilmiah Pendidikan Dasar, 4(2), 230248.

Mahmudi, I. (2011). CIPP: Suatu Model Evaluasi Program Pendidikan. Jurnal At-Ta'dib, 6(1), 111-125.

McDavid, J. C., Huse, I., \& Hawthorn, L. R. (2018). Program Evaluation and performance Measurement: An introduction to The Practice. California: Sage Publications.

Miswanto. (2016). Evaluasi Pelaksanaan Pendidikan Pesantren Mini di Madrasah Aliyaah Patra Mandiri Plaju Palembang. Jurnal of Islamic Education Management, 2(2), 86-104.

Muhtarom, A. (2015). Implementasi Manajamen Sumber Daya Manusia dalam Peningkatan Profesionalitas Dosen Perguruan Tinggi Agama Islam Provinsi Banten. Tarbawi, 1(2), 117-130.

Mulyatiningsih, E., \& Nuryanto, A. (2014). Metode penelitian Terapan bidang Pendidikan. Bandung: Alfabeta

Mutakin, T. Z., Nurhayati, \& Rusmana, I. M. (2014). Penerapan Teori Pembiasaan dalam Pembentukan Karakter Religi Siswa di Tingkat Sekolah Dasar. Edutech, 1(3), 361-373.

Muyasaroh, \& Sutrisno. (2014). Pengembangan Instrumen Evaluasi CIPP pada Program Pembelajaran Tahfiz Al-qur'an di Pondok Pesantren. Jurnal Penelitian Dan Evaluasi Pendidikan, 18(2), 215-233.

Norton, A. (2014). Mapping Australian Higher Education. Victoria: Grattan Institute.

Refita, Y., Siregar, H., \& Imam, S. A. (2017). Evaluasi Program Sarjana Membangun Desa ( SMD ) dan Strategi Pengembangannya ( Studi Kasus Provinsi Sumatera Barat, Jawa Barat dan Nusa Tenggara Barat ). Journal of Regional and Rural Development Planning, 1(1), 98-113.

Rochmawati, U., Timan, A., \& Kusumaningrum, D. E. (2019). Manajemen Pendidikan dan Pelatihan Keahlian Ganda Guru Sekolah Menengah Kejuruan. JAMP: Jurnal Adminitrasi dan Manajemen Pendidikan, 2(3), 147155.

Romdloni. (2017). Manajemen Personalia Sebagai Upaya dalam Meningkatkan Kualitas Personalia di Madrasah. Evaluasi, 1(1), 69-84.

Siswanto, H. B. (2016). Pengantar Manajemen. Jakarta: Bumi Aksara.

Stoner, J. A. F., \& Wankel, C. (1988). Manajemen. Jakarta: Intermedia.

Stufflebeam, D. L., \& Coryn, C. L. S. (2014). Evaluation Theory, Models, and Applications. San Francisco: Jossey-Bass \& Pfeiffer Imprints, Wiley.

Sugiyono, S. (2018). Metode Penelitian Kualitatif untuk Penelitian yang Bersifat: Eksploratif, Enterpretif, Interaktif dan Konstruktif. Bandung: CV. Alfabeta.

Syam, A. R. (2017). Posisi Manajemen Kurikulum dan Pembelajaran dalam Pendidikan. Muaddib: Studi Kependidikan dan Keislaman, 7(01), 33-46.

Syamsuddin. (2017). Penerpan Fungsi-Fungsi Manajemen dalam Meningkatkan Mutu Pendidikan. Jurnal Idaarah, 1(1), 3-4. 
Terry, G. R., \& Rue, L. W. (2019). Dasar-Dasar Manajemen. Jakarta: Bumi Aksara. Toro, J., Requena, I., Duarte, O., \& Zamorano, M. (2013). A Qualitative Method Proposal to Improve Environmental Impact Assessment. Environmental Impact Assessment Review, 43, 9-20.

Widoyoko, E. P. (2017). Evaluasi Program Pembelajaran. Yogyakarta: Pustaka Pelajar.

Wulogening, H. I., \& Timan, A. (2020). Implementasi Total Quality Management ( TQM ) dalam Sistem Manajemen Perencanaan Kepala Sekolah. Jurnal Akuntabilitas Manajemen Pendidikan, 8(2), 137-146.

Zurqoni, Z., Retnawati, H., Apino, E., \& Anazifa, R. D. (2019). Impact of Character Education Implementation: a Goal-Free Evaluation. Problems of Education in the 21st Century, 76(6), 881-899. https://doi.org/10.33225/pec/18.76.881 